\title{
Integrin Beta-1
}

National Cancer Institute

\section{Source}

National Cancer Institute. Integrin Beta-1. NCl Thesaurus. Code C96911.

Integ rin beta-1 (798 aa, $\sim 88 \mathrm{kDa}$ ) is encoded by the human IT GB1 gene. This protein plays a role in leukocyte migration, signal transduction, lig and binding and cell adhesion. 